\title{
An Analysis of Sensory Integration Approach on Counting Skills Among Children With Special-Needs
}

\author{
Syaiful Huda ${ }^{1, *}$ and Nina Agustyaningrum ${ }^{1}$ \\ ${ }^{1}$ Department of Mathematics Education, Riau Kepulauan University, Batam, Indonesia \\ *Corresponding author: syaifulhuda1615@gmail.com; nina@fkip.unrika.ac.id| Phone Number: +6285743695653
}

\section{ARTICLE HISTORY}

Received : 19 May 2019

Revised : 22 June 2019

Accepted : 10 August 2019

\section{KEYWORDS}

Sensory Integration

Approach;

Brain Gym

Meronce (bead stringing)

Counting skills;

ADHD;

\begin{abstract}
This study aims at: (1) knowing whether there is an influence from the sensory integration approach using brain gym treatment and meronce (bead stringing) activities towards counting skills among children with special needs; (2) describing the effect of the sensory integration approach through brain gym treatment and meronce activities on counting skills among children with special needs. This study used the mixed methods with sequential explanatory design. The data analysis techniques were quantitative data analysis with SSR (single subject research) with A-B-A design and qualitative data analysis with data reduction, data display, as well as conclusions drawing and verification. The data were collected from the results of observations, interviews, tests, field notes, and documentations. The objects in this study were the students from the Philea Therapy Center, Batam. Based on the research findings, some conclusions can be drawn as follow: (1) there is a positive effect of the sensory integration approach through brain gym treatment and meronce activities on the counting skills among children with special needs in which the mean level in pre-test (A) was 50 , treatment (B) was 83,33, and post-test (A) was 86.66, respectively; (2) sensory integration approach with brain gym treatment and meronce activities has a positive influence on the counting skills among children with special needs.
\end{abstract}

This is an open access article under the CC-BY-SA license.

\section{INTRODUCTION}

Children with Special Needs (CSN) refer to the children with disorders or developmental barriers. Some cases of CSN include autism, Asperger syndrome, Attention Deficit Hyperactive Disorder (ADHD), and Down syndrome. The characteristics of special needs children are dissimilar one another. Although with the same type, they may have different needs. Actually, if they have correct and proper therapy, they can become extraordinary children.

Based on observations to JP, the students from the Philea therapy center Batam, aged 9 years 8 months as the second grade of elementary school, it was found that JP is a special needs child with ADHD type who has difficulty to follow the lessons in school and to work on counting exercises such as addition and compound subtraction. According to Anderson \& Emmons (2006: 73), "ADHD define as condition that often becomes apparent in preschoolers and early elementary school age. For these children it is hard to pay attention to and control their behavior. ADHD shows children's lack of concentration, hyperactivity, and impulsivity which can cause an imbalance in most of their activities (Rusiana, 2013: 3). To confirm that JP experienced difficulty with numeracy problems, the math pre-test of addition and compound subtraction material was given on September 18, 2016.

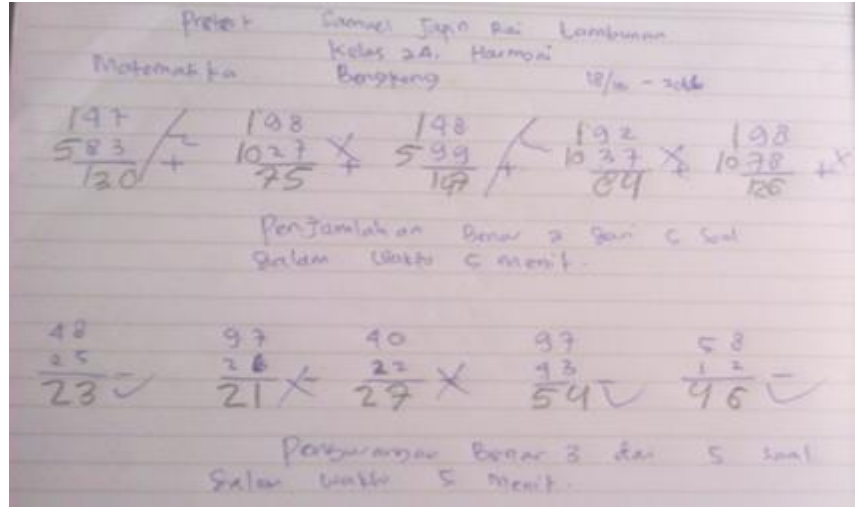

Fig 1. JP's Pre-Test Results On Counting Skills of the 10 given questions, JP was just able to answer

Questions covering 2 questions of addition and 3 items of subtraction. It indicated that JP had difficulty in numeracy and the affecting factors were low of accuracy level, lack of concentration, hurry, and nervousness. Based on the difficulties experienced by JP, a special treatment was made for JP in the form of sensory integration therapy. According to Horowitz and Rost (2007: 4) "sensory integration therapy is a method of treating children who have problems processing sensory stimuli". This means that sensory integration therapy is 
a method applied to children who have problems in processing sensory stimuli. Sensory integration therapy that will be carried out to JP, in the form of a brain gym treatment and meronce (bead stringing) activities.

As stated by Denninson \& Denninson (2008: 3), brain gym is a series of exercises based on simple body movements to facilitate learning activities and to adjust with day-to-day activities. There are a lot of brain gym or movements that can be done, but in this case, it was limited to brain gymnastic movements, such as:

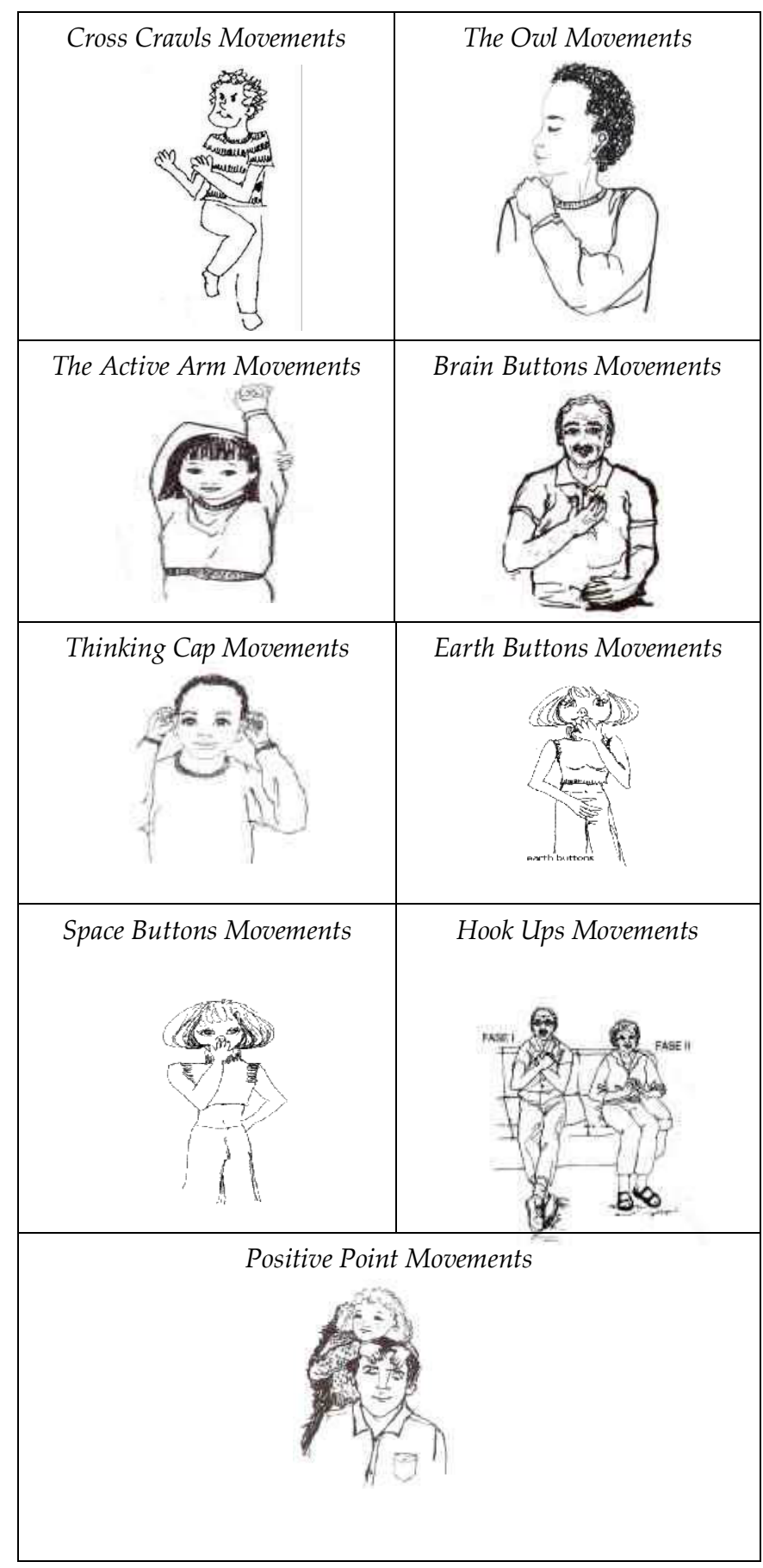

Fig 2. Brain Gym Movements

Its of combining something by inserting a string into small holes on the object. This activity can train the child to think, sharpen their patience in solving problems, train their eyes and hand coordination. It is useful to train their emotions and concentration. Meronce activities done by JP were putting threads into patterned beads that aim to practice focus, concentration and patience. The implementation of brain gym and meronce was for 2 weeks with the duration of 30 minutes in each. Based on the explanation above, it is considered that sensory integration trough the brain gym treatment and meronce suitable to overcome the difficulties on counting skills of CSN.

\section{RESEARCH METHODS}

This research can be categorized as mixed methods with sequential explanatory design. This design used two stages in data collection, the first was quantitatively and the second was qualitatively, that the main emphasis was on the quantitative. According to Creswell (2009: 5), "Mixed methods research is an approach to inquiry that combines or associates both qualitative and quantitative forms".

In this study, the quantitative data were analyzed through within-conditions and between-conditions technique, while the qualitative data were done by using Milles \& Huberman steps including data reduction techniques, data display, as well as conclusions and verification drawing (Satori \& Komariah, 2013: 217). This study was conducted at the Philea Therapy Center Batam on January 10 to 21,2017 and the research subjects were the ADHD children. The data sources used the primary and secondary data. The data collection techniques were observation, interviews, field notes, tests, documentations. The instruments of this study were observation sheets, interview guidelines, counting skills tests with the total of 10 questions containing 5 questions of addition and 5 items of subtraction.

In studies with a single case, the use of complex statistics was not done but rather uses simple descriptive statistics (Sunanto, Takeuchi, \& Nakata, 2005: 56). The quantitative data were analyzed through within-conditions and between-conditions technique, while the qualitative data were done with data reduction, data display, as well as conclusions and verification drawing.

\section{RESULTS AND DISCUSSION}

The obtained data from the test results of counting skills in the pre-test (A1) - treatment (B) - post-test (A2) is presented in the Table 1 as follow.

Table 1. Test Results Of Counting Skills

\begin{tabular}{cc}
\hline $\begin{array}{c}\text { Pre-test }\left(\mathbf{A}_{1}\right) \\
\text { Meeting }\end{array}$ & Score \\
\hline 1 & 50 \\
2 & 50 \\
3 & 50 \\
\hline Treatment (B) & Score \\
Meeting & 70 \\
1 & 80 \\
2 & 90 \\
4 & 90
\end{tabular}




\begin{tabular}{cc}
5 & 80 \\
6 & 90 \\
\hline $\begin{array}{c}\text { Post-test (A } 2) \\
\text { Meeting }\end{array}$ & Score \\
\hline 1 & 80 \\
2 & 90 \\
3 & 90 \\
\hline
\end{tabular}

By comparing the score of pre-test and post-test in Table 1, it can be seen that there was an escalation of JP's counting skills. In details, it is presented in quantitative and qualitative analysis below.

\subsection{Quantitative Data Analysis}

To determine the tendency of the stability of the ability to calculate each pre-test (A1) -treatment (B) -post-test (A2) in this case using a $15 \%$ stability criterion. If the percentage of stability is $85 \%-95 \%$ it is said to be stable while under that it is said to be unstable (Sunanto, Takeuchi, \& Nakata, 2005: 121).

Table 2. The Within-Condition Analysis Results

\begin{tabular}{|c|c|c|c|c|}
\hline No & Conditions & A-1 & B & A-2 \\
\hline 1 & $\begin{array}{l}\text { Condition } \\
\text { duration }\end{array}$ & 3 & 6 & 3 \\
\hline 2 & $\begin{array}{l}\text { Estimation of } \\
\text { direction trend }\end{array}$ & $(=)$ & & \\
\hline 3 & Stability & $\begin{array}{l}\text { Stable } \\
100 \%\end{array}$ & $\begin{array}{l}\text { Variable } \\
83,33 \%\end{array}$ & $\begin{array}{l}\text { Stable } \\
100 \%\end{array}$ \\
\hline 4 & $\begin{array}{l}\text { Trend of data } \\
\text { traces }\end{array}$ & $(=)$ & & \\
\hline 5 & $\begin{array}{l}\text { Stability and } \\
\text { range levels }\end{array}$ & $\begin{array}{l}\text { Stable } \\
(0-50)\end{array}$ & $\begin{array}{l}\text { Variable } \\
(70-90)\end{array}$ & $\begin{array}{l}\text { Stable } \\
(80-90)\end{array}$ \\
\hline 6 & Level change & $\begin{array}{c}(50-50) \\
0\end{array}$ & $\begin{array}{c}(90-70) \\
+20\end{array}$ & $\begin{array}{c}(90-80) \\
+10\end{array}$ \\
\hline
\end{tabular}

Based on Table 2, the condition duration in each phase were 3 meetings in the pre-test (A1), 6 meetings in the treatment (B), and 3 meetings in the post-test (A2). The direction trend for each phase was the baseline (A1) phase showing data stability with the percentage of $100 \%$, the intervention phase (B) with the variable results in the percentage of $83.33 \%$, while the baseline phase (A2) having the stability of $100 \%$. The line in the estimation of the direction and the data traces had the same meaning, namely in the baseline phase (A1) showing the straight direction, while the intervention phase (B) and baseline (A2) indicating an increasing direction. The stability level and the baseline (A1) phase range showing stable data with the range of $0-50$, the intervention phase (B) showing that the data was not variable with the range of 70-90, while in the baseline phase (A2) the data was stable with the range of 80-90. The level change in the baseline (A1) phase indicated the sign (= or 0 ) which mean there was no change, while in the intervention phase (B) and baseline (A2) shows the sign (+) which mean there was better changes.

Table 3. The Between-Condition Analysis Results

\begin{tabular}{clcc}
\hline No. & \multicolumn{1}{c}{$\begin{array}{c}\text { Conditions } \\
\text { Comparisons }\end{array}$} & B/ $\mathbf{A}_{\mathbf{1}}$ & $\mathbf{B} / \mathbf{A}_{\mathbf{2}}$ \\
\hline $1 \quad \begin{array}{l}\text { Number of changed } \\
\text { variables }\end{array}$ & 1 & 1 \\
2 & $\begin{array}{l}\text { Changes of trends } \\
\text { direction }\end{array}$ & $(+)$ & $(+)$ \\
\hline
\end{tabular}

\begin{tabular}{llll}
3 & $\begin{array}{l}\text { Changes of stability } \\
\text { trends }\end{array}$ & $\begin{array}{l}\text { Stable to } \\
\text { Variable }\end{array}$ & $\begin{array}{l}\text { Variable to } \\
\text { Stable }\end{array}$ \\
$40-50$ & $80-90$ \\
4 & Level change & $(+20)$ & $(-10)$ \\
& & $0: 6 \times 100 \%$ & $3: 3 \times 100 \%$ \\
5 & $\begin{array}{l}\text { Percentage of } \\
\text { overlap }\end{array}$ & $(0 \%)$ & $(100 \%)$ \\
\hline
\end{tabular}

Based on Table 3, the number of changed variables in this study was only counting skills. The changes of trend direction in the baseline phase (A1) to the intervention phase (B) were straight to rising which showing the positive trend change, while in the intervention phase (B) to the baseline phase (A2) was rising to rising that indicated the trend change was more positive. The changes in the tendency of the baseline (A1) phase stability to the intervention phase (B) was stable to the variable and intervention (B) to the baseline phase (A2) was variable to stable. The changes in the level between the baseline (A1) phase and the intervention phase (B) showed $(+)$ in terms of the range of data points, which mean improving, while the intervention phase (B) with the baseline phase (A2) showed data (-) from the point data range which mean decreasing. The percentage of overlap data showed $0 \%$ for the baseline phase (A1) to intervention (B) and 100\% for intervention (B) to baseline (A2).

\subsection{Analysis of Qualitative Data}

Table 4. Observation Results From The First Until Sixth Day

\begin{tabular}{|c|c|c|c|c|c|c|c|}
\hline \multirow{2}{*}{ Observation } & \multirow{2}{*}{$\begin{array}{l}\text { Observed } \\
\text { aspects }\end{array}$} & \multicolumn{4}{|c|}{ Meeting of } & \multirow[b]{2}{*}{5} & \multirow[b]{2}{*}{6} \\
\hline & & 1 & 2 & 3 & 4 & & \\
\hline \multirow[t]{2}{*}{ Accuracy level } & $\begin{array}{l}\text { Doing the } \\
\text { task } \\
\text { seriously }\end{array}$ & $\mathrm{S}$ & B & B & B & B & B \\
\hline & $\begin{array}{l}\text { Doing the } \\
\text { task correctly }\end{array}$ & $\mathrm{B}$ & $\mathrm{B}$ & SB & SB & $\mathrm{B}$ & SB \\
\hline \multirow[t]{2}{*}{ Concentration } & $\begin{array}{l}\text { Doing the } \\
\text { task calmly }\end{array}$ & $\mathrm{S}$ & $\mathrm{S}$ & $\mathrm{S}$ & $\mathrm{S}$ & B & B \\
\hline & Focusing & $\mathrm{S}$ & $\mathrm{S}$ & $\mathrm{S}$ & $\mathrm{S}$ & $\mathrm{B}$ & B \\
\hline \multirow[t]{2}{*}{ Hurry } & $\begin{array}{l}\text { Doing the } \\
\text { task } \\
\text { effectively }\end{array}$ & SB & SB & $\mathrm{SB}$ & SB & BS & $\mathrm{SB}$ \\
\hline & Relax & $\mathrm{S}$ & $\mathrm{S}$ & $\mathrm{S}$ & $\mathrm{S}$ & $\mathrm{B}$ & $\mathrm{B}$ \\
\hline \multirow[t]{2}{*}{ Confidence } & $\begin{array}{l}\text { Keeping eyes } \\
\text { on the task }\end{array}$ & $\mathrm{S}$ & $\mathrm{S}$ & $\mathrm{S}$ & $\mathrm{S}$ & B & B \\
\hline & $\begin{array}{l}\text { Being } \\
\text { confident } \\
\text { with own } \\
\text { results } \\
\end{array}$ & $\mathrm{s}$ & $\mathrm{S}$ & $\mathrm{S}$ & $\mathrm{S}$ & B & B \\
\hline
\end{tabular}

$\begin{array}{ll}\text { Explanation: } \\ \mathrm{K} & : \text { Bad } \\ \mathrm{S} & : \text { Moderate } \\ \mathrm{B} & \text { : Good } \\ \mathrm{SB} & : \text { Excellent }\end{array}$

As the observation result of brain gym treatment and meronce activities for 6 days in Table 4, JP's behavior got better day to day and it assisted JP to overcome the difficulties in counting. The interview with JP's mother on January 24, 2017 supported that there was an improved behavior change from JP after receiving treatment. JP became more diligent in learning and doing assignments from the school. Moreover, JP teachers 
were also interviewed on February 2, 2017, and they stated that JP showed some improvements in attitudes. They also mentioned that JP was formerly noisy, difficult to sit quietly and annoying the classmates but, JP behavior was 180 degree changed after having treatment.

Based on the within and between conditions results, JP had performed some progress in overcoming on counting problem. The interviews with JP's mothers and teachers also indicated the improvements in JP behavior and learning patterns that contribute to overcome the learning difficulties in the schools. Through this case, it can be inferred that the sensory integration approach gave a meaningful influence to the target behavior. These findings support the opinions of Denninson \& Denninson (2008: 3), the pioneers of the brain gym since 1970. The brain gym was originally designed to overcome learning disorders in children who experience hyperactivity, brain damage, concentration problems, and depression. Meanwhile, Syafrol (2013: 7) has pointed out that the benefits of meronce activities for children are to train the child to think, sharpen their patience in solving problems, train their eyes and hand coordination by inserting a string into small holes of objects. Those are truly useful for train child's emotions and concentration. Therefore, sensory integration therapy with brain gym treatment and menronce can assist JP to overcome the problems in the schools related to the counting skills.

\section{CONCLUSION}

Based on the research findings, some conclusion can be drawn as follow.

1. There is a positive influence from the sensory integration approach with brain gym treatment and meronce activities towards counting skills among children with special needs (CSN) that can be seen from the post-test results with the mean score of 86.66 .

2. The sensory integration approach with brain gym treatment and meronce activities has a positive influence on counting skills among children with special needs (SCN) through brain gym movements such as cross crawls, owl movements, the active arm, brain buttons, the thinking cap, the earth buttons, the space buttons, the hook ups, the positive points and meronce (bead stringing).

The following recommendations for research are based on the study findings.

1. The parents can independently give treatment of sensory integration as an alternative way to overcome the problems on hyperactive children.

2. For further researches, it is recommended to involve the subjects with different characteristics and increase the number of the sessions and the duration.

\section{REFERENCES}

Dysfunction: Learning, Development and Sensory Dysfunction in Autism Spectrum Disorder, ADHD, Learning Disabilities and Bipolar Disorder. London: Jessica Kingsley Publishers.

Creswell, John W. (2009). Research Design: Qualitative, Quantitative, and Mixed Methods Approaches. London: SAGE Publications, Inc.

Denninson, Paul E. \& Denninson, Gail E. (2008). Brain Gym and Me. Jakarta: PT Grasindo.

Horowitz, L. \& Rost, C. (2007). Helping Hyperactive Kids-A Sensory Integration Approach: Techniques and Tips for Parents and Professionals. Alameda: Hunter House
Publishers.

Rusiana, E. (2013). Pendekatan sensori integrasi untuk meminimalisir perilaku hiperaktif pada anak autis. Jurnal Pendidikan Khusus, 3(3), 1-10.

Syafrol, D. (2013). "Peningkatan Konsentrasi Belajar Anak Autis dalam Berhitung melalui keterampilan Meronce". Jurnal. Diambil pada tanggal 18 November 2016, dari http://download.portalgaruda.orgarticle.

Satori, D. \& Komariah, A. (2013). Metodologi penelitian kualitatif. Bandung: CV Alfabeta.

Sunanto, J., Takeuchi, K., \& Nakata, H. (2005). Pengantar Penelitian Dengan Subyek Tunggal. Tsukuba: CRICED University of Tsukuba. 